\title{
Increasing Students' Awareness in Speaking Participation
}

Received: February 03, 2018

doi: $10.30587 /$ jetlal.v3i1.788

\author{
Ribeh Najib Muhammad \\ Universitas Muhammadiyah Gresik \\ ribeh@umg.ac.id
}

Accepted: February 15, 2019

Published: February 27, 2019

\begin{abstract}
The lack of students' activities seems to be the main reasons why the teacher failed to maximize the participation of the students in a senior high school in a small city in East Java Indonesia. The unification of two different basic competences into one lesson plan also makes the indicator of the lesson plan become not too clear and not specific enough. Thus the research questions of this study are: 1 . How is the implementation of the teaching and learning process based on the revised lesson plan conducted by the teacher? 2. How is the teaching and learning process based on the revised lesson plan followed by the students? 3. How is the students' participation in learning speaking after the teaching and learning process based on the revised lesson plan conducted? This research is a classroom action research with one cycle only. The first data is in the form of description of the teacher's activities during the teaching and learning process, the source of the data is the teacher who conducts the revised teaching-learning process. The second data is the description of students' activities during the teaching and learning process, the source of the second data is the students who follow the teaching and learning process based on the revised lesson plan. The third data is the participation of the students when they are taught using the revised lesson plan, the third source of the data is also the students who follow the teaching and learning process based on the revised lesson plan. The researcher used unstructured field notes to write all the information which were seen and heard and also everything that happened during teaching and learning process conducted by the teacher. The data need to be sorted and classified to know the relevant data and non-relevant data. Then the relevant data were classified based on each research question to be analyzed. The students' participation in the teaching and learning process of speaking narrative text based on the revised lesson plan was better, because the students could follow the instructions and do the activities of speaking narrative text smoothly, every student was able to present their stories in the group and in front of the class, they were active in the group discussion for asking and answering their friends' question, they were also active in asking questions to the teacher and answering questions from the teacher.
\end{abstract}

\section{Keywords: Improving, Participation, Speaking, Lesson Plan}

\section{Introduction}

Students' participation is important to build opportunities for all students to be successful learners by being confident and creative individuals. So improving participation is an obvious goal in courses that include frequent discussions and small-group work. In short, if only a few students participate by volunteering answers, asking questions, or contributing to discussions, class sessions become to some extent a lost opportunity to evaluate and promote teaching and learning process. A teacher can improve students' participation in his course by devoting time and thought then shaping the environment and planning each class session. Furthermore, the way in which the teacher interacts, both verbally and non-verbally, communicates to the students about his attitude relating to participation (Davis, 1993). Therefore it is important for the teacher to be able to manage active student participation, because it does not happen naturally in speaking courses, it must be carefully planned and encouraged throughout the teaching and learning process of every lesson including English, from elementary school until university level.

In the twelfth grade of science study 1 of a senior high school in a small city in East Java Indonesia, the teaching of English lesson is conducted twice a week, there are 32 students with most of them are female students. The class is large enough, with clear sunlight from the windows, there is no fan or $\mathrm{AC}$, but the air is not too hot, the chairs and tables are arranged perfectly by the students. When the teacher taught them the sub basic competence 4.2.1 which is about expressing the meaning of monologue text using oral language features 
accurately, smoothly, and correctly in daily life context in the text of: narrative with the speaking skill, there were a few students in the front row who silently focused and followed the teacher's instruction, while several others had an empty look in their faces. Although the teacher used clear and loud voice and interracted with all students, the teacher could not maximize students' participation in learning and practicing the competence because until the class ended many students chose to be passive. Although there were a few students who eagerly spoke up, the rest of them just kept silent or spoke reluctantly. The activity to practice the speaking skill which was conducted by the teacher and students was story telling, the students did monologue of narrative text individually. While one of their friends presented his/her narrative text, other students were recording it. So it needed a lot of time to make all the students speak and practice their narrative text. This activity was continued on the second meeting, the students who did not get the change to present their narrative on the previous meeting must present on the second meeting.

The lack of students' activities seemed to be the main reasons why the teacher failed to maximize the participation of the students, because in teaching speaking, students need to be given a lot of time to practice. So, more oral emphasis should be given in the teaching to give students as much speaking time as possible (Klancar, 2006). Although it is not easy to make students speak as the teacher wants, they could be encouraged to do that with the suitable approach.

As for the lesson plan (Appendix 1), it has one basic competence and one sub basic competence written in one lesson plan which make the lesson plan rather confusing, because the focus is diffused. Those competences are; 1. Basic competence 3.2 expressing the meaning of transactional dialogue (to get things done) and interpersonal (socialize) formal and continuously (sustained) accurately, smoothly, and correctly in the daily life context and involving speech acts: admitting mistakes, giving promise, blaming, accusing, expressing curiosity and expressing intensions, And 2. Sub basic competence 4.2.1 expressing the meaning of monologue text using oral language features accurately, smoothly, and correctly in daily life context in the text of: narrative. The unification of two different basic competences into one lesson plan also makes the indicator of the lesson plan become not too clear and not specific enough; the indicator for the second competence only says that the students can express the monologue of narrative text without mentioning the factors which are needed by the students to accomplish first. The materials used are from the students, they bring their own story to be told to their friends. For the learning objective, it is related to the indicator, so there is only one objective written in the lesson plan. Teacher and students activities are clearly mentioned, but it is quite difficult to understand and follow. The assessment written in the lesson plan is product assessment only, there is no process assessment.

The classroom activities in the lesson plan are not varied enough; teacher only makes the student present their text one by one while others record it, it needs a long time to finish, so there is not enough time for students to practice their speaking skill, beside that some students seem do not care with their friends who present their work. The activities conducted in the teaching process should be as intensive as possible, the students can also memorize the vocabularies, expressions and terms automatically even without realizing that they have master several vocabulary and expressions in English. Therefore, it is essential that language teachers pay great attention to teaching speaking. Rather than leading students to pure memorization, providing a rich environment where meaningful communication takes place is desired (Kayi, 2006).

From the previous information, it is important to know how to improve the students' participation in order to make them more enthusiastic for speaking up their ideas when the teaching and learning process is conducted in their classroom. Certain things in the lesson plan are needed to be changed to make the students speak with their own will and great participation. It is very important to join with the students' world to make them participating with teacher's activities. Because once a teacher can get the students' attention and participation, it means that the teacher has won half of the battle, but if the teacher cannot get the students' attention and then their participation, the teacher has been lost before the battle begins. The revision of the lesson plan to give the solution for the problems include adding and formulating more specific indicators, adjusting the learning objectives to indicators, choosing the suitable material for the students, designing teacher's and student's activities clearly and making the suitable process assessment. The presented material was made by the students, the teacher only prepare some examples for them, and then they have to make their text as they want with the guidance from the teacher and their friends.

\section{Method}

This research is a classroom action research. Susanto (2010a) says that classroom action research is a research about implementation of teaching and learning in the classroom. It is an approach employed by a teacher and conducted with one or more researchers to improve the quality of education by first getting an evaluation from the unsuccessful previous study. In this research, there is one researcher who collaborates with a teacher. The problem of this research comes from the classroom, so before conducting the research, the researcher must first recognize the students' capability and the weaknesses of the previous lesson. Here the researcher knew the students' capability and the teacher's teaching through discussion with the teacher and previewing the previous students' participation. 
Classroom action research is a research about a teaching learning process in the classroom; it must be praxis rather than practice. Praxis is informed, committed action that gives rise to knowledge rather than just successful action (McNiff, 1988). It was because action research involves other people as partner and it led to knowledge from and about educational practice. In this study, the researcher made a collaborative research with the teacher. So the main goal for a classroom action research is to improve the practices rather than to produce knowledge. The design of action research based on Susanto (2010a) can be illustrated plainly as follows:

From the hypothesis stated in the first chapter, this research was started by making the revised lesson plan (RPP-P: Rencana Pelaksanaan Pembelajaran Perbaikan) (Appendix 2) which was made after doing reflection of the observation of the teaching and learning process that was conducted before, and also based on the analysis of the previous lesson plan (RPP-T: Rencana Pelaksanaan Pembelajaran Terdahulu) (Appendix 1) used for that teaching and learning process. Then the teaching-learning process based on the revised lesson plan was conducted by the teacher, while the observation and reflection on the field was conducted by the researcher. After finishing the teaching and learning process, the teacher and the researcher gathered to discuss the data and the result of the reflection then conducting evaluation and making the conclusion. Because the conclusion was satisfying then the research was stopped without the revision of the lesson plan as the preparation of the second cycle.

\section{Setting of the Study}

The setting of the study is a science study class of a senior high school in a small city in East Java Indonesia. The class consists of 32 students; 10 male students and 22 female students. This school has implemented the recent curriculum, KTSP, in which the school has the right under the government regulation to make their own belief in designing syllabus based on the vision, mission, and the goals they want to achieve. Besides, the school has also become an RSBI categorized school even though the English program to conduct all lessons has not yet been done totally. The English class where the researcher conducts his research is held twice a week.

\section{Research Procedure}

In conducting this research, there were several steps or procedures which were applied chronologically in order to get the valid data and information related to the previous lesson plan and revised lesson plan that need to be practiced for the teaching and learning process in the classroom. Those steps were as follows:

After having a discussion about the students' ability, problems and weaknesses, the teacher and the researcher prepared everything which was needed during the teaching and learning process. The preparation and the planning stage conducted based on the students' problems and weaknesses, in this case was the lack of students' participation in the teaching and learning process.

The teacher and the researcher made the revised lesson plan (Appendix 2) and prepared field notes to record all the things that happened during teaching and learning process in order to make the teaching and learning process could be done effectively.

In revising the lesson plan, the researcher needed to add and formulate more specific indicators, adjust the learning objectives with the indicators, choose the suitable material for the students, design teacher's and student's activities clearly and make the suitable process assessment. The presented material is made by the students, the teacher only prepared some examples for them, and then they had to make their text as they wanted with the guidance from the teacher and their friend. Several groups were made to create cooperation in the same group and competition with the other groups, as Fan (2007) states that competition is very effective to arouse students' interests. Students' activities were focused on the preparing speaking and speaking practice; they practiced speaking from the smaller area like their own group then moved to the bigger area like the classroom.

What the researcher and the teacher had planned in the planning stage was implemented in this stage. In this stage the teacher conducted teaching learning process based on the revised lesson plan.

The researcher observed and conducted on-field reflection of the classroom activities by using field notes towards what happened in the classroom during the teaching learning process. In observing stage, the researcher observed everything that happened in the classroom which was done by the teacher and also by the students. The reflection was conducted at the same time based on the implementation of the revised lesson plan.

The last stage is reflecting. In this stage the teacher and researcher evaluated and discussed the result of the observation and on-field reflection. The teacher and researcher discussed all information of teaching and learning process based on the record taken by using unstructured field notes, and then analyzed the students' performance in order to know the students' participation.

Because the students' participation improved, the teaching and learning process applied in the classroom accomplished the goals, the teacher and the researcher did not make a revision in the lesson plan for the next cycle, as the second cycle was not needed. 


\section{Data and Source of Data}

There are three kinds of qualitative data; the data of the study were in the form of information collected to answer the research questions of the study. Data is the factual information, often in the form of facts or figures obtained from experiments or surveys, used as a basis for making analysis or drawing conclusions. Source of data is the people or everything where the data could be gotten. The first data is in the form of description of the teacher's activities whether it is verbal or non-verbal during the teaching and learning process, these data are needed to answer the first research question (How is the implementation of the teaching and learning process based on the revised lesson plan?). The source of the data is the teacher who conducts the revised teaching-learning process. The second data is the description of students' activities during the teaching and learning process, whether they are verbal or non-verbal, these data are needed to answer the second research question (How is the teaching and learning process based on the revised lesson plan followed by the students?). The source of the second data is the students who follow the teaching and learning process based on the revised lesson plan. The third data is the participation of the students when they are taught using the revised lesson plan, these data are needed to answer the third research question (How is the students' participation in learning speaking after the teaching and learning based on the revised lesson plan conducted?). The third source of the data is also the students who follow the teaching and learning process based on the revised lesson plan.

\section{Data Collection Technique}

The researcher is the key instrument in this research to collect all the data which are needed to answer the research questions. The researcher used unstructured field notes to write all the information which were seen and heard and also everything that happened during teaching and learning process conducted by the teacher. Bogdan and Biklen (2003) says that field note is the written account of what the researcher hears, sees, experiences, and thinks in the course of collecting and reflecting on the data in a qualitative study. Then the field notes were organized to descriptive notes and reflective notes. Descriptive notes concern to provide a word-picture of the setting, people, actions, and conversations as observed (Bogdan and Biklen, 2003); this kind of note is used to note down everything observed in the progress of the teaching and learning process including teacher's talk, students' activities, etc. The other one is reflective notes; this kind of notes captures more of the observer's frame of mind, ideas, and concerns (Bogdan and Biklen, 2003). Reflective notes were used by the researcher to conduct reflection in the field or on-field analysis for the data observed. The foundation of the observation is the congruity between the teaching learning process and the revised lesson plan.

\section{Data Analysis}

The data collected in this research is very abundant, but not all the data are relevant with the requirement, it needs to be processed systematically (Susanto, 2010a). So the data need to be sorted and classified to know the relevant data and non-relevant data. Then the relevant data were classified based on each research question to be analyzed. This analysis was conducted to describe the revised teaching-learning process, results of the analysis, explanation and discussion, and conclusion making.

\section{Findings and Discussion}

\section{The Implementation of the Teaching and Learning Process Based on the Revised Lesson Plan Conducted by the Teacher}

In revising the lesson plan, the researcher added and formulated more specific indicators, adjusted the learning objectives to indicators, chose the suitable material for the students, designed teacher's and student's activities clearly and made the suitable process assessment. The material was prepared by the students, the teacher only prepared some examples for them, and then they made their text as they wanted with the guidance from the teacher and their friend. Several groups were made to create cooperation in the same group and competition with the other groups, because competition is very effective to arouse students' interests. Students' activities were focused on the preparing speaking and speaking practice; they practiced speaking from the smaller area like their own group then moved to bigger area which was the classroom.

In this study, researcher took field notes from the observation for the teaching process conducted by the English teacher on the students of twelfth grade of science study 1 of a senior high school in a small city in East Java Indonesia. The observation to the teaching and learning process based on the revised and improved lesson plan showed that the teacher conducted the teaching process very well. Based on the unstructured field notes which were produced by the observer, the teacher conducted all the steps of the revised lesson plan smoothly and chronologically.

The teacher conducted the activities by following the steps which are written in the revised lesson plan (Appendix 2). The teacher performed the opening with greeting, giving apperception and motivation to the 
students. In the first meeting, it showed that the teacher was very enthusiastic and joyful when she greeted her students.

The teacher started the lesson by giving greeting "Assalamualaikum Warahmatullahi Wabarakatuh" All the students answer together by saying "Waalaikumsalam Warahmatullahi Wabarakatuh". Then the teacher greeted the students with clear and loud voice "Hello, good morning, how are you today?". The students replied with "Good morning, I am fine, thank you". The teacher said "you're welcome"

The teacher gave apperception about the lesson by saying "Today we are going to have speaking class, we are going to learn about speaking narrative text, we have learned about narrative text, who can mention the generic structure of narrative text?". The students eagerly answered together with "Orientation, Complication, and Resolution." The teacher response with "very good, today we are going to practice it together; everybody must speak, because I will take score of your speaking practice."

Then the teacher continued to the main activities, the first activity is to divide the students into several groups, each group consisted of four members. To encourage her students to be accustomed to speak English in her class, she always use English every time, her English was easy to understand because she used simple English with slows pace (1).

(1) T: Ok Class, I need you to make several groups, you will do your work in your groups, each group consists of four students ok?

S: Ok bu, acak atau pilih sendiri bu?

$\mathrm{T}$ : $\quad$ Based on your number in the attendance list, ok come on, move quickly.

The communication in English classroom usually takes place between the teacher and one student in a conference about work done or to be done. In person-to-person communication in a group, students can converse informally; interview their friends, even brainstorm. They can also try to inform, define, direct, persuade, entertain; and in the process, they can learn to adjust their speech to accomplish these different purposes with different individuals of the group.

In their groups, students can discuss, ask and answer to all their friends who belong to the group. This will give them better understanding about the duties, they would also start to become more confident and ready to act or present as they have practiced their performances in their groups.

The next activity conducted by the teacher was giving the example of narrative texts to all group, this is to make the students have the right perception of a good narrative text with its generic structure without having to limit the students' creativity (2).

(2) T: Ok, every group has got an example of narrative text, is that right?

Yes mam

S: $\quad$ Now you can decide the title of narrative text that you want to use, you can use

$\mathrm{T}$ : Indonesian story or foreign story, it is up to you.

In contrary with the use of teacher's standardized material which is given to all the students, that will make certain or even most of the students feel that they are being forced in doing their work, and that will make the students feel reluctant for exposing and maximizing their creativity, it is very important to give freedom to the students for choosing the title and material for their narrative text, because when the students like something, they will automatically give their best to do it, they will also take the full responsibility of the thing that they chose.

The teacher started to make the students make their narrative text in their group; she told them that they can discuss everything related to their work with their friends in the same group or with the teacher. She moved around the class, from a group to another group to help her students make good narrative texts (3)

(3) $\mathrm{T}$ : Ok then, after you have the title, you can start with the content, do not forget the generic structure, what is the generic structure once more?

Orientation, complication, re-orientation

S: Good, now you can start writing the text like the examples, you can discuss

$\mathrm{T}$ : with your friend in the group or ask me. 
The teacher often give some questions to her students in the end of her explanation, this is very good in establishing joyful and cooperative atmosphere in the classroom. When students consider their teacher as a person they could talk easily to, they will try to express their mind and their feeling, although they do not know the answers or they know that they have the wrong idea for their answers.

When the teacher thought that the students has spend enough time in making their narrative texts, she announced that the time for them to write their text was finished, and then the students had to present their works in front of the class without mentioning the title, because it was the duty of other students to try guessing the title (4).

(4) T: ok class, time is up, time for discussion is over, now it is the time for you to present your work in front of the class

S: $\quad$ ya bu kurang sedikit,

T: no, that's enough, who want to present now?

S: me mam

T: Good, come forward, do not forget not to mention the title ok?

S: Ok mam, understand

T: for you, pay attention to her and try to guess the title of the story she told.

There were some students who raised her hand to come forward, and the teacher chose the students who would have the opportunity to come forward. There were only three students who had the opportunity, but it was enough to give the other students clear examples of what would they do in the next meeting. The other students paid good attention to the presenters, because they were curious with the title, in this meeting all the titles of the stories could be guessed, they were Snow White, and two stories with the same title "I love you more than salt".

In the second meeting, after greeting and having some talks with the students, the teacher reviewed their activities in the previous meeting and what should they do on that meeting (5).

(5) T: class, what have we done in the previous meeting?

S: Making narrative text and present it mam,

T: good job, today we will just continue our activities in the previous meeting, now go to your group once more, make sure you do not change your group kalo yang sudah maju kemarin gimana mam?

S: $\quad$ same with the others, go to your group and help your friends

T:

The teacher ordered all the students to pay attention to their friend of their group who were presenting, and gave comment and opinion to the presentation. She moved around visiting every group to help the students and to give score for their speaking practice (6).

(6) T: now every one of you has to present your work to your friends of your group in turn, after that the students who do not present have to give comments to the student who present their story, do you understand? gentian ya mam?

S: yes that's right, in turn

T:

Finally the teacher stopped the group work, and told the students that it was the time for them to present their work one by one in front of the classroom, before made them remember not to mention the title for it was the duty of their friends outside their group (7).

(7) $\mathrm{T}$ : ok now all of you have finish practicing, now you are ready to present your work in front of the class like what we did in the previous meeting, but now 
everyone has to come forward to present their work and other students except his group have to guest the title,

S: yes mam

The teacher always gave response and comments toward the students' performances in front of the class, she commented about their intonation, vocabularies, structures, gesture, and expression (8).

(8) T: very good, you have presented your story with good intonation and various vocabularies, I also like your gesture and expression, you just have to improve your pronunciation, okay? Overall you are very good.

The result of the observation indicated that the teacher could control all the students of her class and conducted the teaching learning process effectively. The process gave a clear view that the teaching and learning process using the revised lesson plan exactly similar with the hypotheses (Teacher applies the steps of teaching and learning process as written in the revised lesson plan, including reformulation of indicator, selection of new material, formulation of teacher's main activities, students' activities, and addition of process assessment item).

We could say that by revising the original lesson plan could improve the teaching and learning process. With a good lesson plan which is complying with the competence standard and the basic competence of the learning closely, the teacher has the right direction in teaching her students to be able to speak more actively.

\section{The Teaching and Learning Process Based on the Revised Lesson Plan Followed by the Students}

Based on the observation conducted by the researcher, the teacher conducted teaching and learning process as written in the revised lesson plan, and the students were doing the learning activities given by the teacher. The students were eager to learn English, it could be seen when their English teacher entered to the class. They shouted the greeting to her. The teacher asked the students about what they would learn. Before the teacher started new lesson, the teacher reviewed about the previous lesson.

The students were explained about what they were going to learn, especially the type of the text, which was going to be discussed. The teacher needed to inform all information which was related to the type of the text so that they knew the objective of the teaching learning process. Hopefully, by informing the objective, they could understand and do the best activity. Most activities that were involved in this phase were oral activity. The teacher had to be active in order to direct the students in the teaching and learning process. Even though the teacher must be active, it did not mean that the students were passive in the teaching learning process. On the other hand, the active participant of the students was needed in the speaking. It was needed since the main goal is the aim at arising the students' ability to speak.

After the students were informed about the text they would discuss, for example, the Teacher asked them to mention the generic structure of narrative text. From that responses that the teacher always motivate and encourage them actively to participate in class especially English class. In this case, motivation is very important because if people or students are motivated, they intend to accomplish something and undertake goal-oriented action to do so. It means that when students are motivated the goal will be achieved. Then some questions were asked by the teacher.

After greeting and having some talks with the students, the teacher reviewed the previous meeting such as, the generic structure, vocabularies, and connector of sequences related to narrative text. These were done to recall the students' memory whether they still remembered or not. Since the students were on the group, all the students could answer all the questions from the teacher.

The lesson started with greeting from the teacher "Assalamualaikum Warahmatullahi Wabarakatuh" All the students answer together by saying "Waalaikumsalam Warahmatullahi Wabarakatuh". Then the teacher greeted the students with clear and loud voice "Hello, good morning, how are you today?". The students replied with "Good morning, I am fine, thank you". The teacher said "you're welcome"

The teacher said to the students "Today we are going to have speaking class, we are going to learn about speaking narrative text, we have learned about narrative text, who can mention the generic structure of narrative 
text?". The students eagerly answered together with "Orientation, Complication, and Resolution." The teacher response with "very good, today we are going to practice it together, everybody must speak, because I will take score of your speaking practice."

Then the students were ordered to create several groups based on the attendance list, and most of the students followed her instructions directly, despite of some students who were reluctant to move from their seats (9)

(9) T: Ok Class, I need you to make several groups, you will do your work in your groups, each group consists of four students ok?

S: Ok bu, acak atau pilih sendiri bu?

$\mathrm{T}$ : Based on your number in the attendance list, ok come on, move quickly. grup 1 dimana bu?

S: $\quad$ group 1 in that corner, group 2 there, group 3 here, and so on

T:

When the teacher used English all the time, some of the students still prefer to use their own language which is Indonesian to answer or ask; it is because some of the students still do not have the ability to speak English spontaneously, so they still feel shy of their error in structure or pronunciation.

The students then were explained about the narrative text and ordered to make their own stories with the right steps based on the generic structures, from the title, orientation, complication, and reorientation. The students also followed and did the instructions of the teacher as written in the revised lesson plan (10)

(10) $\mathrm{T}$ : now you can decide the title of narrative text that you want to use, you can use Indonesian story or foreign story, it is up to you can we use this example?

S: of course, as long as only the title not the content, do you understand?

T: understand

Ok then, after you have the title, you can start with the content, do not forget

$\mathrm{S}: \quad$ the generic structure, what is the generic structure once more?

$\mathrm{T}$ : Orientation, complication, re-orientation

S:

In group discussion, there were some students that liked to monopoly the discussion, these students had better speaking skill than the other members of their group, but this was not disturbing as long as the teacher could control them and all the students in the group were able to ask and answer the questions given by their friends.

Most of the students were very eager to present their stories, they often used various gestures and facial expression which supported the stories which were presented by them. So their friends of the same group became aroused and interested to hear and follow their stories with great enthusiasm. They paid attention to their friends who told the stories; they became totally understood about what they had to do.

\section{Students' Participation in Learning Speaking When the Teaching and Learning Process Based on the Revised Lesson Plan Conducted}

From the observation in the classroom, students' participation in speaking practice was very good, they were able to participate in the teaching and learning process based on the revised lesson plan conducted by the teacher, it is as expected by both the teacher and the researcher. While the teaching and learning process was being conducted by the teacher, the students gave cooperative and enthusiastic responses, they also produced concerned behaviors (11).

(11) $\mathrm{T}$ : class, what have we done in the previous meeting?

S: Making narrative text and present it mam

$\mathrm{T}$ : ok, who can explain narrative text?

S: me mam, text that tell about story to entertain

$\mathrm{T}$ : Very good, and the generic structure?

$\mathrm{S}$ : Orientation, complication, and resolution 
The teacher conducted teaching and learning process as written in the revised lesson plan and students participated cooperatively in every activity given by the teacher related to learning speaking. They behaved well although they have some questions to ask, they did it respectfully, the students' pay attention to the explanation given by their teacher carefully and quietly. There were two or three students who chose to make conversation with their friends. But it wasn't long enough. The students feel interested and curious with the duty or job given by the teacher to them.

They liked that they can choose their own material, so they can explore their belief, love, and creativity. The students also encouraged to give their maximum potential because of the hot atmosphere of competition throughout the classroom (12).

(12) T: ok now all of you have finish practicing, now you are ready to present your work in front of the class like what we did in the previous meeting, but now everyone has to come forward to present their work and other students except his group have to guest the title yes mam

S: Who want to present first?

T: $\quad$ Me mam

S:

The students always gave responses to the teacher's questions and orders, they all wanted to take the opportunity to answer or ask the teacher. When they joined in their groups, which were consisted of four members, they had a lot of discussion in their group, they discussed their narrative text with their friends, and then in turn, they presented their story in their group.

In the groups, students were very active in making and then practicing or presenting their text in front of their friends in that group. When a student was presenting, his friends of the same group listened and gave some correction and suggestions for his performance. They felt free and courageous to correct and criticize their friends because they knew that it would not give them problems, as the one who presented is their own friend. The process of presenting and being criticized became a little awkward when the teacher was near to them, it seemed that some students feel shy of their speaking ability, and some students wanted to show to their teacher in order to make the teacher notice about their extraordinary speaking ability.

By doing this group discussion, the students could make their text better because their friends gave the suggestions and opinion, they could also strengthen their confidence before presenting their text in front of the class, because they could know what is good and what is not good from their presentation in their group. They felt free to express their emotion when telling their narrative story to their friends of the group; they used their expression and gesture. sometimes the students feel that they were totally free from the teacher's supervision, so they just speak without knowing that they make mistake, but the teacher know this and give the correction directly. For the result when all the students presenting one by one without mentioning the title and using good intonation and gestures, their teachers felt very satisfied with their performances (13).

(13) T: very good, you have presented your story with good intonation and various vocabularies, I also like your gesture and expression, you just have to improve your pronunciation, okay? Overall that was very good Thank you mam

S:

It could be said that the students' participation in the teaching and learning process of speaking narrative text based on the revised lesson plan was better, because the students could follow the instructions and do the activities of speaking narrative text smoothly. With only one cycle, the goals could be achieved, thus the second cycle is not needed. The participation is mainly viewed from the fact that every student was able to present their stories in the group and in front of the class, they were active in the group discussion for asking and answering their friends' question, they were also active in asking questions to the teacher and answering questions from the teacher. The narrative texts presented by the students were: Pinocchio, Beauty and the Beast, and Rapunzel on the first meeting, Peterpan, Rabbit and Turtle, Malin Kundang, Timun Emas, Timun Emas, Cinderella, Rapunzel, Titanic, Snow White, Bawang Merah Bawang Putih, Sleeping Beauty, Romeo And Juliet, Pinocchio, Sangkuriang, Red Riding Hood, Little Mermaid, Rapunzel, Jaka Tarub, Cinderella, Beauty And The Beast, Lake Toba, Larva, Lake Toba, Beauty And The Beast, Red Riding Hood, Malin Kundang, and Cinderella on the second meeting. 


\section{Conclusion}

Based on the previous chapter, which is about the result and discussion, the researcher has made the conclusion that the revised lesson plan followed by the implementation of teaching and learning process based on the revised lesson plan could improve the students' participation in a speaking class. This research was conducted by a researcher and a teacher in one cycle of two meetings. The observation showed that the implementation of the revised lesson plan produced the improvement of the students' participation in the teaching and learning process of speaking narrative text in the twelfth grade of science study. In the improved teaching and learning process using revised lesson plan the teacher accommodated the students to be more interested and aroused in practicing their speaking ability because the activities conducted in the classroom were very student-centered. As for the students, they had more time to practice their speaking skill inside their group and in front of the classroom, so they could present their best performance to their teacher and their friends. It could be concluded from the researcher's finding that by revising the lesson plan could make the teaching and learning process especially in speaking class better.

\section{References}

Bean, Jack C. \& Peterson, Dean. 1998. Grading classroom participation: New Directions for Teaching and Learning. Seattle: Seattle University Press.

Bogdan, R. C. \& Biklen, S. K. 2003. Qualitative Research for Education: An Introduction to Theory and Methods $\left(4^{\text {th }} e d\right)$. New York: Pearson Education Group Inc.

Davis, Barbara-Gross. 1993. Tools for Teaching. San Francisco: Jossey-Bass.

Depdiknas. 2006. Standar Isi: Standar Kompetensi Lulusan Mata Pelajaran Bahasa Inggris (SD/MI, SMP/MTs, SMA/MA, SMK). Jakarta: Departemen Pendidikan Nasional.

Ellis, Rod. 1990. Instructed second language acquisition. Oxford: Basil Blackwell.

Fan, Ma Lai. 2007. Finding effective ways to increase students' confidence to speak English in class. Hong Kong: Lingnan University Press.

Janice, Skowron. 2006. Powerful Lesson Planning: Every Teachers Guide to Effective Instruction. California: Corwin Press.

Jones, Leo. 2007. The Student-Centered Classroom. New York: Cambridge University Press.

Kayi, Hayriye. 2006. Teaching Speaking: Activiti 43 TESL journal: Vol. XII No. 11

e Speaking in a Second Language. The Internet

Klancar, Natasa Intihar. 2006. Developing Speak http://iteslj.org/Techniques/Klancar-Speaking Skills.html

the Young Learners Classroom. Retrieved from

Marzano, R. 1988. Dimensions of Thinking: A Framework for Curriculum and Instruction. Virginia: Alexandria.

McNiff, Jean. 1988. Action Research: Principles and Practice. London: Routledge.

Nunan, David. 1999. Second Language Teaching and Learning. Boston: Heinle\&Heinle Publishers.

Nunan, David. 2003. Practical English Language Teaching. New York: McGraw-Hill.

Peck, Robert. 1978. Teacher Characteristics that Influence Students' Evaluations. Washington D.C.: Microfiche.

Richards, Jack C. 1990. Conversationally speaking: approaches to the teaching of conversation. New York: Cambridge University Press.

Roby, T. W. 1988. "Models of Discussion." In J. T. Dillon (ed.), Questioning and Discussion: A Multidisciplinary Study. New Jersey: Ablex. 
Susanto. 2010a. Konsep Penelitian Tindakan Kelas dan Penerapannya. Surabaya: Lembaga Penerbitan FBS Unesa.

Susanto. 2010b. Silabus dan RPP Mata Pelajaran Bahasa Inggris. Surabaya: Lembaga Penerbitan FBS Unesa.

Weimer, Maryellen. 2009. The Teaching Professor: Uses for Participation. New York: Magna Publications. 